\title{
STUDI ANALISIS PENGELOLAAN PRAKTIKUM KEAGAMAAN ISLAM Perspektif Kurikulum
}

\author{
Kisbiyanto
}

Jurusan Tarbiyah STAIN Kudus

\begin{abstract}
This study used a qualitative approach, to describe the (1) curriculum policy planning charged practices in Islamic learning, (2) form of charged practice curriculum in the learning of Islam, (3) curriculum implementation and evaluation in Islamic learning. Research results: (1) There are 63 subjects containing 155 credits in Islamic Religious Education at Tarbiyah Department of Kudus Islamic State College of Islam have clearly been prepared their practicums, at least there are eight practicums, including: Arabic, English, worship, information and technology, research, profession/micro teaching, field professional practicums, and real practice (KKN). The eighth subjects arenamed practicum courses, (2) in addition, there are 20charged forms of the practice course, 24 other regular subjects, but have a lab charge, and of the twenty- four, decent into practicum courses are statistics, both descriptive and inferential, (3) the implementation of learning to eight practicum courses, offered in sequence from the first half to eight semesters, charged by evaluating the curriculum refers to the practice of learning and evaluation system. Passing valuation of each subject is specified minimum value of 2.00, except Field Professional Practice (PPL) that must reach a minimum value of 3.49 .
\end{abstract}

Keywords: Management, Islamic Religious Practicum

\section{A. Pendahuluan}

\section{Latar Belakang Masalah}

Penyelenggaraan pendidikan pada program studi tertentu di perguruan tinggi agama Islam Negeri (PTAIN) mempunyai dimensidimensi keilmuan dan tujuan-tujuan khusus. Program studi pendidikan agama Islam, pendidikan bahasa arab, pendidikan guru madrasah ibtidaiyah, pendidikan guru raudlatul athfal, manajemen pendidikan Islam, tadris matematika, tadris IPA, tadris IPS, dan sebagainya pada 
fakultas/jurusan Tarbiyah juga akan mempunyai tujuan yang khusus, kurikulum yang khusus, dan standar evaluasi yang khusus. Masalahmasalah terkait dengan pendidikan sangat banyak.

Kendala umum dalam pembelajaran adalah masalah kurikulum. Kurikulum yang statis akan menjadi materi didik yang tertinggal dengan perkembangan sosial yang cepat. Kurikulum harus dinamis, sesuai dengan perkembangan sosial budaya. Kurikulum yang berbudaya adalah yang selalu dipelajari kembali sehingga sesuai dengan misi pendidikan dalam pembentukan kepribadian dan keahlian manusia (HAR. Tilaar:1999).

Masalah lain dalam kurikulum adalah tentang isi kurikulum yang tidak sesuai dengan tujuan yang diharapkan. Isi kurikulum seharusnya merujuk pada rumusan tujuan atau sesuai dengan visi dan misi pendidikan. Kesenjangan ini harus diatasi dengan upaya penyesuaian terhadap tujuan. Komponen kurikulum (Nasution 1993:34) yang terdiri dari tujuan, bahan pelajaran, proses belajar mengajar dan penilaian harus dirumuskan secara serasi, selaras dan seimbang, baik untuk kurikulum nasional maupun kurikulum muatan lokal.

Masalah lebih khusus dalam pemberlakuan kurikulum adalah yang terkait dengan standar evaluasi. Evaluasi terkadang kurang terukur sehingga evaluasi dilakukan tanpa standarisasi sesuai kurikulum yang ideal. Evaluasi sebagai komponen penting kurikulum juga sering tidak dirumuskan secara jelas, meskipun tidak semua aspek penilaian itu diukur dengan angka. Kejelasan standarisasi evaluasi pada rumusan kurikulum akan membantu upaya pencapaian tujuan melalui proses evaluasi yang valid dan reliabel.

Namun, gejala di atas tidak menyeluruh. Perguruan tinggi tertentu mempunyai strategi khusus dalam kurikulum terutama untuk mengatasi masalah relevansi. Kurikulum pada program studi pendidikan agama Islam sebagai bagian dari rumpun ilmu pendidikan Islam (ilmu tarbiyah), mempunyai dua aspek teoritik dan praktik. Ilmu pendidikan islam merupakan ilmu teoritik sekaligus ilmu praktik. Karenanya, pembelajaran agama Islam harus mendapat perhatian khusus pada aspek teoritik maupun praktiknya. Kurikulum teoritik tentulah menjadi bahan wajib. Kurikulum praktik juga menjadi penting, misalnya praktik ibadah, praktik mengajar, dan semacamnya. Upayaupaya pengembangan kurikulum di perguruan tinggi tersebut sangat menarik karena merupakan bidang penting dalam perkembangan pendidikan dewasa ini.

\section{Fokus Penelitian}

Penelitian ini adalah tentang kurikulum praktik pada 23 Volume 1, Nomor 1, Juli-Desember 2013 
pembelajaran agama Islam, yang secara rinci difokuskan pada hal-hal sebagai berikut :

a. Bagaimana perencanaan kebijakan kurikulum bermuatan praktik pada pembelajaran agama Islam di STAIN Kudus?

b. Bagaimana bentuk kurikulum bermuatan praktik pada pembelajaran agama Islam di STAIN Kudus?

c. Bagaimana pelaksanaan dan evaluasi kurikulum bermuatan praktik pada pembelajaran agama Islam di STAIN Kudus?

\section{Batasan Masalah}

Banyak masalah dalam hal berkaitan dengan kurikulum bermuatan praktik pada perguruan tinggi agama Islam, namun dalam penelitian ini dibatasi cakupan pembahasannya pada aspek: (1) perencanaan kebijakan kurikulum bermuatan praktik pada pembelajaran agama Islam di STAIN Kudus, (2) bentuk kurikulum bermuatan praktik pada pembelajaran agama Islam di STAIN Kudus, (3) pelaksanaan dan evaluasi kurikulum pada pembelajaran agama Islam di STAIN Kudus.

\section{a. Tujuan Penelitian}

Penelitian ini lakukan dengan tujuan sebagai berikut :

1) Menjelaskan perencanaan kebijakan kurikulum bermuatan praktik pada pembelajaran agama Islam di STAIN Kudus.

2) Menjelaskan bentuk kurikulum bermuatan praktik pada pembelajaran agama Islam di STAIN Kudus.

3) Menjelaskan pelaksanaan dan evaluasi kurikulum bermuatan praktik pada pembelajaran agama Islam di STAIN Kudus.

\section{b. Manfaat Penelitian}

Penelitian ini diharapkan dapat memberikan manfaat, baik secara teoritis maupun secara praktis sebagai berikut :

1) Manfaat teoritis penelitian ini adalah kajian tentang perencanaan dan pengembangan kurikulum dalam ilmu pendidikan Islam, yaitu kurikulum bermuatan praktik di pergutuan tinggi agama Islam.

2) Manfaat praktis penelitian ini adalah memberikan informasi dan masukan kepada para pengelola dan pendidik, serta perguruan tinggi yang menyelenggarakan pendidikan agama Islam, baik untuk dosen, mahasiswa, dan para ahli dan praktisi pendidikan tinggi khususnya, dan semua pendidikan secara luas. 


\section{B. Kajian Pustaka}

\section{Kurikulum dan Pengembangannya}

\section{a. Kurikulum Perguruan Tinggi}

Menurut Subandijah (1996:2-3) dalam bukunya Pengembangan dan Inovasi Kurikulum, yang dimaksud kurikulum adalah "aktifitas dan kegiatan belajar yang direncanakan, diprogramkan bagi peserta didik di bawah bimbingan sekolah, baik di dalam maupun di luar sekolah". Isi definisi tersebut dapat diklasifikasi menjadi dua substansi, yaitu (1) kurikulum sebagai program yang direncanakan dan dilaksanakan di sekolah dan (2) kurikulum sebagai program yang direncanakan dan dilaksanakan secara nyata di kelas. Perencanaan program dan pelaksanaannya tersebut dimaksudkan untuk mencapai tujuan pendidikan yang telah ditetapkan. Dengan demikian, kurikulum berkedudukan sebagai alat untuk mencapai tujuan pendidikan.

Pendidikan tinggi di Indonesia melaksanakan proses pembelajaran dengan mengacu pada kurikulum nasional. Di samping itu, lembaga pendidikan juga menerapkan kurikulum muatan lokal yang ditentukan oleh masing-masing satuan lembaga pendidikan. Kedua macam kurikulum itu merupakan keharusan bagi setiap lembaga pendidikan untuk menerapkannya. Menurut UU RI No. 20 Tahun 2003, kurikulum pendidikan wajib memuat: pendidikan agama, pendidikan kewarganegaraan, bahasa, dan ilmu-ilmu dasar dan ilmu-ilmu terapan yang mendukung tujuan pendidikan masingmasing fakultas, jurusan, dan program studi. Sedangkan menurut UU RI No. 12 Tahun 2012, kurikulum pendidikan tinggi wajib memuat agama, pancasila, kewarganegaraan, dan bahasa Indonesia.

Jadi disamping materi yang telah ditentukan secara nasional, sebuah lembaga pendidikan harus menentukan dan mengajarkan kurikulum muatan lokal yang didesain, diajarkan lembaga pendidikan tertentu. Muatan lokal merupakan kurikulum institusional yang ditujukan untuk membekali peserta didik dengan kekhususan tertentu. Kurikulum dengan muatan praktik biasanya didesain oleh perguruan tinggi di fakultas/jurusan masing-masing.

\section{b. Pengembangan Kurikulum}

Pengembangan kurikulum menurut Hendyat Soetopo dan Wasty Soemanto (1986:41) adalah "kegiatan menghasilkan kurikulum baru melalui langkah-langkah penyusunan, pelaksanaan dan penyempurnaan kurikulum atas dasar hasil penilaian yang dilakukan selama kegiatan pengembangan tersebut". 
Sedang pengembangan kurikulum menurut Centre for Educational Research and Innovation (CERI) dalam rumusan Soetopo (1986:45) didefinisikan sebagai berikut:

"curriculum development is the proces of analizing and refining goals, aims and objectives, together with the translation of these into the content of course by formal or informal methods".

Kegiatan pengembangan kurikulum meliputi penyusunan kurikulum, pelaksanaannya di dalam proses belajar mengajar dan penyempurnaan terhadap komponen-komponen tertentu atas dasar hasil penilaian.

\section{c. Landasan Pengembangan Kurikulum}

Menurut Nasution (1993:1-2), pengembangan kurikulum didasarkan atas asas-asas tertentu, yaitu: (1) asas filosofis yang pada hakekatnya menentukan tujuan umum pendidikan, (2) asas sosiologis yang memberikan dasar untuk menentukan apa yang akan dipelajari sesuai dengan kebutuhan masyarakat, budaya dan perkembangan ilmu pengetahuan dan teknologi, (3) asas organisatoris yang memberikan dasar-dasar dalam bentuk bagaimana bahan pelajaran disusun dan bagaimana luas dan urutannya, dan (4) asas psikologis yang memberikan prinsip-prinsip tentang perkembangan manusia dalam berbagai aspek serta cara belajar agar bahan yang disediakan dapat dicerna dan dikuasai peserta didik sesuai dengan taraf perkembangannya.

Hendyat Soetopo dan Wasty Soemanto (1986:46) menerangkan bahwa landasan pengembagan kurikulum dapat menjadi "titik tolak" sekaligus menjadi "titik sampai". Titik tolak berarti pengembangan kurikulum dapat didorong oleh pembaharuan tertentu seperti penemuan teori belajar yang baru dan perubahan tuntutan masyarakat. Titik sampai berarti kurikulum harus dikembangkan sedemikian rupa sehingga dapat merealisasikan perkembangan tertentu, seperti impak kemajuan ilmu pengetahuan dan teknologi, tuntutan-tuntutan sejarah masa lalu, perbedaan latar belakang peserta didik, nilai-nilai filsafat suatu masyarakat dan tuntutan-tuntutan kultur tertentu.

\section{d. Perencanaan Kurikulum}

Perencanaan menurut St. Vembriarto (1993:28) dalam bukunya Pengantar Perencanaan Pendidikan adalah penggunaan analisis yang bersifat rasional dan sistematis terhadap proses pengembangan pendidikan yang bertujuan untuk menjadikan pendidikan lebih efektif dan efisien dalam menanggapi kebutuhan 
dan tujuan peserta didik dan masyarakat.

Ada empat persoalan penting yang dibahas dalam perencanaan, yaitu (1) tujuan apa yang dicapai dengan perencanaan itu, (2) status sistem pendidikan yang ada dan bagaimana keadaannya sekarang, (3) kemungkinan-kemungkinan pilihan apa yang ditempuh untuk mencapai tujuan, dan (4) strategi yang terbaik untuk mencapai tujuan.

Jadi perencanaan dalam pendidikan adalah sebagai fungsi manajemen pendidikan. Fungsi perencanaan tersebut adalah untuk menentukan keadaan yang sebaik-baiknya dari hubungan-hubungan sumber daya internal dan eksternal dalam suatu sistem pendidikan dengan keadaaan yang dinamis serta cara yang efisien dan efektif untuk mencapai tujuan yang diinginkan.

Salah satu sumber daya yang harus direncanakan adalah "materi pendidikan" atau kurikulum. Sumber daya "kurikulum" ini membutuhkan perencanaan yang tepat dan strategis. Hasil perencanaan kurikulum yang baik menentukan keberhasilan dalam pencapaian tujuan pendidikan. Dalam konteks perkembangan, kurikulum harus selalu dikembangkan. Fungsi perencanaan kurikulum dan pengembangnnya itu dimaksudkan untuk pengelolaan pendidikan agar tidak mengalami ketertinggalan.

\section{e. Faktor-faktor Pengembangan Kurikulum}

Soetopo (1986:40-41) mengemukakan tiga faktor umum yang mendorong pengembangan kurikulum, yaitu (1) perubahan yang diinginkan masyarakat sehingga mereka merencanakan adanya perubahan yang cukup penting di dalam kurikulum dan sistem pendidikan, (2) perkembangan ilmu pengetahuan dan teknologi yang pesat, dan (3) pertambahan pesat penduduk dunia.

Menurut Nasution(1993:159) dalambukunya Pengembangan Kurikulum, proses pengembangan kurikulum dijalankan karena (1) hasil penelitian dan pengembangan, (2) interaksi sosial, dan (3) metode pemecahan masalah.

\section{f. Prinsip-prinsip Pengembangan Kurikulum}

Menurut Soetopo (1986:48), prinsip-prinsip dasar pengembangan kurikulum meliputi: (1) prinsip relevansi, yang meliputi relevansi dengan lingkungan, perkembangan masa dan tuntutan dunia kerja, (2) prinsip efektifitas yang meliputi efektifitas mengajar pendidik dan efektifitas belajar peserta didik, (3) prinsip efisiensi dalam penggunaan sumber daya pendidikan.

Prinsip-prinsip pengembangan kurikulum menurut 27 
Subandijah (1993:48) adalah: (1) prinsip relevansi, (2) prinsip efektifitas dan efisiensi, (3) prinsip kesinambungan, (4) prinsip fleksibilitas, (5) prinsip berorientasi pada tujuan, (6) prinsip pendidikan seumur hidup, dan (6) prinsip kesesuaian dengan model pengembangan kurikulum.

\section{g. Pendekatan dan Model Pengembangan Kurikulum}

Pendekatan dalam pengembangan kurikulum diorientasikan pada (1) tujuan pendidikan dan (2) bahan pelajaran. Subandijah (1993:55) mengemukakan tiga pendekatan dengan pola organisasi bahan sebagai berikut: (1) pendekatan dengan pola subject matter curriculum, yaitu pendekatan yang menekankan pada mata pelajaran/mata kuliah secara terpisah-pisah, (2) pendekatan dengan pola corelated curriculum, yaitu pendekatan dengan pola pengelompokan beberapa mata kuliah yang seiring (serumpun), dan (3) pendekatan dengan pola integrated curriculum, yaitu pendekatan dengan penyatuan keseluruhan mata kuliah sebagai bahan ajar yang sistematik-integralistik.

\section{h. Tahap-tahap Pengembangan Kurikulum}

Langkah-langkah utama dalam perencanaan kurikulum misalnya dengan model Tyler dalam Nasution (1993:140) meliputi (1) menentukan tujuan pendidikan, (2) menentukan proses belajar mengajar, (3) menentukan organisasi kurikulum, dan (4) menentukan cara penilaian hasil belajar.

Adapun tahap-tahap dalam pengembangan kurikulum menurut Subandijah (1993:215) adalah: (1) pengembangan kurikulum pada tingkat lembaga, (2) pengembangan kurikulum pada tingkat/setiap bidang studi, dan (3) pengembangan pengajaran di kelas.

Tahap-tahap pengembangan kurikulum di perguruan tinggi dijalani secara terstruktur, sepanjang masa dari tahun ke tahun selama satu periode pemberlakuan kurikulum berkisar antara 4 hingga 5 tahun.

\section{Pendidikan Islam}

Pendidikan mempunyai nilai dari aspek pengertiannya, yaitu at-tarbiyah, at-ta'lim, dan at-ta'dib. Para pakar pendidikan islam memberikan menjelasan yang beraragam namun mempunyai titik temu bahwa pendidikan Islam pada hakekatnya mempunyai banyak makna.

Pertama, pendidikan Islam dalam disebut al-tarbiyah yang berasal dari kata rabb (Nizar 2002:26). Walaupun kata ini memiliki banyak arti, akan tetapi pengertian dasarnya menunjukkan makna tumbuh, 
berkembang, memelihara, merawat, mengatur, dan menjaga kelestarian atau eksistensinya. Dalam penjelasan lain, kata al-tarbiyah berasal dari tiga kata, yaitu: Pertama, rabba-yarbu yang berarti bertambah, tumbuh, dan berkembang (QS. Ar Ruum/30: 39). Kedua, rabiya-yarba berarti menjadi besar. Ketiga, rabba-yarubbu berarti memperbaiki, menguasai urusan, menuntun, dan memelihara. Kata rabb sebagaimana yang terdapat dalam QS. Al Fatihah/1: 2 (alhamdu li Allahi rabb al-'alamin) mempunyai kandungan makna yang berkonotasi dengan istilah al-Tarbiyah. Sebab kata rabb (Tuhan) dan murabbi (pendidik) berasal dari akar kata yang sama. Berdasarkan hal ini, maka Allah adalah Pendidik Yang Maha Agung bagi seluruh alam semesta.

Pendidikan dalam bahasa Arab (Roqib 2009:14) biasa disebut dengan istilah tarbiyah yang berasal dari kata kerja rabba, sedang pengajaran dalam bahasa Arab disebut dengan ta'lim yang berasal dari kata kerja 'allama. Pendidikan Islam sama dengan Tarbiyah Islamiyah. Kata rabba beserta cabangnya banyak dijumpai dalam Al-Qur'an, misalnya dalam QS. Al-Isra' [17]:24 dan QS. Asy-Syu'ara' [26]:18, sedang kata 'allama antara lain terdapat dalam QS. al-Baqarah [2]:31 dan QS. anNaml [27]:16. Tarbiyah sering juga disebut ta'dib seperti sabda Nabi Saw.: addabani rabbi fa ahsana ta'dibi (Tuhanku telah mendidikku, maka aku menyempurnakan pendidikannya).

Pendidikan yang dalam bahasa Arab disebut tarbiyah itu merupakan derivasi dari kata rabb seperti dinyatakan dalam QS. Fatihah [1]:2, Allah sebagai Tuhan semesta alam (rabb al-'alamin), yaitu Tuhan yang mengatur dan mendidik seluruh alam. Allah memberikan informasi tentang arti penting perencanaan, penertiban, dan peningkatan kualitas alam. Manusia diharapkan selalu memuji kepada Tuhan yang mendidik alam semesta karenanya manusia juga harus terdidik agar memiliki kemampuan untuk memahami alam yang telah dididik oleh Allah sekaligus mampu mendekatkan diri kepada Allah Sang Pendidik Sejati. Sebagai makhluk Tuhan, manusia idealnya melakukan internalisasi secara kontinu (istiqamah) terhadap nilai-nilai ilahiyah agar mencapai derajat insan kamil (manusia paripurna) sesuai dengan kehendak Allah SWT (Roqib 2009:14).

Nilai konsep tentang pendidikan Islam itu sendiri teramat luas jangkauannya karena menyangkut berbagai bidang yang berkaitan dengannya, mulai dari pengertian, dasar, tujuan, pendidik, subyek didik, alat-alat, kurikukum, pendekatan dan metode, lingkungan sampai pada lembaga pendidikan. Oleh karena itu, dalam buku ini penulis hanya akan membahasnya secara singkat dengan lebih memberikan titik tekan pada fungsi edukasi masjid sebagai pusat pendidikan dan 
pemberdayaan (Roqib 2009:4). Penggunaan term al-tarbiyah untuk menunjuk makna pendidikan Islam dapat dipahami dengan merujuk firman Allah, yaitu: "Dan rendahkanlah dirimu terhadap mereka berdua dengan penuh kesayangan dan ucapkanlah: "Wahai Tuhanku, kasihilah mereka keduanya, sebagaimana mereka berdua telah mendidik aku waktu kecil" (QS. Al Isra' /17: 24). Uraian di atas, secara filosofis mengisyaratkan bahwa proses pendidikan Islam adalah bersumber pada pendidikan yang diberikan Allah sebagai "pendidik" seluruh ciptaan-Nya, termasuk manusia. Dalam konteks yang luas, pengertian pendidikan Islam yang dikandung dalam term al-tarbiyah terdiri atas empat unsur pendekatan, yaitu: (1) memelihara dan menjaga fitrah anak didik menjelang dewasa (baligh). (2) mengembangkan seluruh potensi menuju kesempurnaan. (3) mengarahkan seluruh fitrah menuju kesempurnaan. (4) melaksanakan pendidikan secara bertahap (Nizar 2002:26).

Kedua, istilah al-ta'lim telah digunakan sejak periode awal pelaksanaan pendidikan Islam. Menurut para ahli, kata ini lebih bersifat universal dibanding dengan al-tarbiyah maupun al-ta'dib. Rasyid Ridha, misalnya mengartikan al-ta'lim sebagai proses transmisi berbagai ilmu pengetahuan pada jiwa individu tanpa adanya batasan dan ketentuan tertentu. Sebagaimana firman Allah SWT: "Sebagaimana (Kami telah menyempurnakan ni'mat Kami kepadamu) Kami telah mengutus kepadamu Rasul diantara kamu yang membacakan ayat-ayat Kami kepada kamu dan mensucikan kamu mengajarkan kepadamu Al Kitab dan Al-Hikmah (As Sunnah), serta mengajarkan kepada kamu apa yang belum kamu ketahui." (QS. Al Baqarah/2: 151).

Ketiga, pendidikan Islam disebutat-ta'dib. Menurutal-Attas, istilah yang paling tepat untuk menunjukkan pendidikan Islam adalah $a l-t a ' d i b$. Konsep ini didasarkan pada hadits Nabi: "Tuhan telah mendidikku,maka Ia sempurnakan pendidikanku”.(HR. Al-Askary dari 'Ali r.a.).

Kata addaba dalam hadits di atas dimaknai al-Attas sebagai "mendidik". Selanjutnya ia mengemukakan, bahwa hadits tersebut bisa dimaknai kepada "Tuhanku telah membuatku mengenali dan mengakui dengan adab yang dilakukan secara berangsur-angsur ditanamkanNya kedalam diriku, tempat-tempat yang tepat bagi segala sesuatu didalam penciptaan, sehingga hal itu membimbingku kearah pengenalan dan pengakuan tempat-Nya yang tepat didalam tatanan wujud dan kepribadian, serta sebagai akibatnya Ia telah membuat pendidikanku yang paling baik. Berdasarkan batasan tersebut, maka al-ta'dib berarti pengenalan dan pengakuan yang secara berangsur-angsur ditanamkan kedalam diri manusia (peserta didik) tentang tempat-tempat yang tepat dari segala sesuatu didalam tatanan penciptaan. Dengan pendekatan 
ini, pendidikan akan berfungsi sebagai pembimbing kearah pengenalan dan pengakuan tempat Tuhan yang tepat dalam tatanan wujud dan kepribadiannya (Nizar 2002:30).

Terlepas dari perdebatan makna dari ketiga term diatas, secara terminologi, para ahli pendidikan Islam telah mencoba memformulasi pengertian pendidikan Islam. Diantara batasan yang sangat variatif tersebut adalah (Nizar 2002:32) :

1. al-Syaibaniy; mengemukakan bahwa pendidikan Islam adalah proses mengubah tingkah laku individu peserta didik pada kehidupan pribadi, masyarakat, dan alam sekitarnya. Proses tersebut dilakukan dengan cara pendidikan dan pengajaran sebagai suatu aktivitas asasi dan profesi diantara sekian banyak profesi asasi dalam masyarakat.

2. Muhammad Fadhil al-Jamaly; mendefinisikan pendidikan Islam sebagai upaya mengembangkan, mendorong serta mengajak peserta didik hidup lebih dinamis dengan berdasarkan nilai-nilai yang tinggi dan kehidupan yang mulia. Dengan proses tersebut, diharapkan akan terbentuk pribadipeserta didik yang lebih sempurna, baik yang berkaitan dengan potensi akal, perasaan, maupun perbuatannya.

3. Ahmad D. Marimba; mengemukakan bahwa pendidikan Islam adalah bimbingan atau pimpinan secara sadar oleh pendidik terhadap perkembangan jasmani dan rohani peserta didik menuju terbentuknya kepribadiannya yang utama (insan kamil).

4. Ahmad Tafsir; mendefinisikan pendidikan Islam sebagai bimbingan yang diberikan oleh seseorang agar ia berkembang secara maksimal sesuai dengan ajaran Islam.

\section{Metode Penelitian}

\section{Pendekatan Penelitian}

McMillan (2001:29) menjelaskan bahwa penelitian dengan pendekatan kualitatif mempunyai beberapa model, yaitu etnografi, fenomenologi, studi kasus, grounded theory, critical studies, concept analysis dan historical analysis.

Model yang digunakan dalam penelitian ini adalah studi kasus dengan karakter utama dari pendekatan kualitatif adalah bukan dimaksudkan untuk menguji suatu teori, tetapi untuk mengungkapkan fenomena dan realitas melalui data-data secara deskriptif. Data-data spesifik dicari maknanya untuk membuat kesimpulan yang general dari makna-makna yang diperoleh dari data-data tersebut.

Penelitian ini dirancang untuk menjelaskan tentang kurikulum bermuatan praktik pada pembelajaran agama Islam di STAIN Kudus. 


\section{Subyek dan Sumber Penelitian}

Sumber informasi utama dalam penelitian ini adalah perancang dan pengelola kurikulum di STAIN Kudus. Untuk memperoleh data yang absah, sumber informasi ditentukan secara purposif, yaitu para responden yang dianggap bisa memberikan data yang akurat, maka dituju sebagai sumber yang pokok. Peneliti mengklasifikasi sumbersumber tersebut dalam pembagian bidang yang diteliti tentang kurikulum bermuatan praktik apada pembelajaran agama Islam di STAIN Kudus.

\section{Lokasi dan Waktu Penelitian}

Agar diperoleh kesesuaian antara persoalan yang fokus dengan setting penelitian, sebagaimana dianjurkan oleh Moleong (1994), dilakukan penjajakan dan penilaian lapangan, dalam hal ini adalah pada Program Studi Pendidikan Agama Islam STAIN Kudus.

Penelitian dengan pendekatan kualitatif tidak ditentukan batas waktu secara jelas sampai peneliti memperoleh pemahaman yang benar-benar mendalam tentang obyek yang diteliti. Namun karena pertimbangan dan keterbatasan waktu, biaya dan tenaga, maka penelitian dapat diakhiri dan dibuat laporannya jika dianggap telah mencapai data dan analisis sesuai dengan rancangan. Namun demikian, penelitian ini tetap dibatasi waktu, yaitu dilaksanakan sepanjang awal hinggá September 2012.

\section{Teknik Pengumpulan Data}

Untuk pengumpulan data, penelitian ini menggunakan beberapa teknik, yaitu pengamatan/observasi, wawancara dan dokumentasi. Dalam pengamatan, dua hal penting (Nasution, 1996:58) yang diperhatikan, yaitu informasi dan konteks. Dengan ketepatan dalam menghubungkan keduanya, maka didapat maknanya, karena makna diperoleh dari keterkaitan antara informasi dan konteksnya. Bentuk pengamatan yang dilakukan dalam penelitian ini ada tiga, yaitu: (1) pengamatan secara deskriptif, (2) pengamatan secara terfokus, dan (3) pengamatan selektif.

Dokumentasi dilakukan untuk mendapatkan informasi dari sumber yang berupa dokumen/arsip, foto, dan bahan statistik yang lain. Data diperoleh dari dokumentasi data-data, baik yang berupa tulisan/ dokumen resmi maupun dokumen pribadi seperti makalah, artikel, catatan dan surat-surat, misalnya buku panduan, buku laporan, buku laporan dan sebagainya.

\section{Keabsahan Data}

Agar data yang diperoleh, yang berujung pada kesimpulan 
atau verifikasi, dapat dipertanggungjawabkan secara ilmiah, maka dilakukan pemeriksaan keabsahan data. Teknik yang digunakan dalam pemeriksaan keabsahan data dalam penelitian ini, sebagaimana dikatakan Moleong (2001) meliputi: perpanjangan keikutsertaan, ketekunan pengamatan, triangulasi, pemeriksaan sejawat, kecukupan referensi, kajian kasus negatif dan pengecekan. Namun, dalam penelitian ini, tidak semua teknik di atas digunakan, hanya beberapa teknik yang tepat dan diperlukan saja yang digunakan.

Untuk pengecekan keabsahan data menggunakan empat kriteria Moleong (2001), yaitu derajat kepercayaan (credibility), keteralihan (transferablity), kebergantungan (dependability) dan kepastian (confirmability).

\section{Teknik Analisis Data}

Analisis data merupakan proses mencari dan mengatur secara sistematis transkrip wawancara, cacatan lapangan, dan bahan-bahan lain yang telah dihimpun untuk menambah pemahaman menganai bahan-bahan penelitian untuk memungkinkan mendapat temuan sebagai hasil penelitian (Bogdan 1990). Untuk memberikan pemaknaan atas data atau fenomena yang ditemukan dan dikumpulkan dalam penelitian ini, maka dilakukan analisis dengan pendekatan kualitatif dengan eksplanasi bersifat deskripsi. Dengan teknik analisis deskriptif, langkah yang ditempuh dalam analisis ini adalah mengorganisir data berupa gambar, foto, dokumen yang berupa laporan, biografi, artikel, buku-buku pedoman dan sebagainya (Moleong, 2001:103).

Selanjutnya data-data yang diperoleh dianalisis dengan model siklus interaktif sebagaimana dikemukakan oleh Milles dan Huberman (1992:20). Proses ini dilakukan selama proses penelitian ditempuh melalui serangkaian proses pengumpulan, reduksi, penyajian dan verifikasi data.

\section{Hasil Penelitian}

Kurikulum pada pembelajaran agama Islam Jurusan Tarbiyah Sekolah Tinggi Agama Islam Negeri Kudus yang terdiri dari 63 mata kuliah berbobot 155 sks, telah disusun dengan diperjelas mata kuliah praktiknya, sekurangnya pada praktikum-praktikum yang dicanangkan, yaitu ada delapan (8) mata kuliah praktikum, meliputi: praktikum bahasa Arab, praktikum bahasa Inggris, praktikum ibadah, praktikum teknologi informasi, praktikum penelitian, praktikum profesi/micro teaching, praktik profesi lapangan, dan kuliah kerja nyata. Kedelapan tersebut dinamakan mata kuliah praktikum. Jadi perencanaan kurikulum yang jelas-jelas bermuatan praktik sudah mencapai 8 dari 63 mata kuliah, atau 20 sks 
dari 155 sks. Jika diprosentasi mencapai 12,9 \% dari keseluruhan bobot kurikulum. Perencanaan kurikulum itu dituangkan sebagai sebaran mata kuliah yang diformat per semester sebagai berikut:

Di samping itu, masih ada dua puluh empat (24) mata kuliah yang bisa bernuansa praktik karena isi maupaun cakupannya memerlukan praktik sebagai lahitan bagi mahasiswa. Kedua puluh empat tersebut bermuatan praktikum mata kuliah. Artinya, mata kuliah itu disusun tidak semata-mata untuk praktik, tetapi di dalam isi mata kuliah itu memuat unsur untuk kerja praktik bagi mahasiswa. Misalnya mata kuliah fiqih ibadah membutuhkan praktik baik dalam bentuk simulasi, demosntrasi, atau lainnya.

Bentuk kurikulum untuk praktikum keagamaan disusun dengan komponen kode mata kuliah, kelompok jenis mata kuliah, program studi, strata kesarjanaan, bobot sistem kredit semester, banyak pertemuan empat belas kali, waktu sesuai bobot kredit, standar kompetensi, kompetensi dasar, indikator, materi pokok, metode pembelajaran, sistem penilaian, serta bahan dan sumber belajar.

\section{E. Penutup}

\section{Simpulan}

a. Kurikulum pada pembelajaran agama Islam Jurusan Tarbiyah Sekolah Tinggi Agama Islam Negeri Kudus yang terdiri dari 63 mata kuliah berbobot 155 sks, telah disusun dengan diperjelas mata kuliah praktiknya, sekurangnya pada praktikum-praktikum yang dicanangkan, yaitu ada delapan (8) mata kuliah praktikum, meliputi : praktikum bahasa Arab, praktikum bahasa Inggris, praktikum ibadah, praktikum teknologi informasi, praktikum penelitian, praktikum profesi/micro teaching, praktik profesi lapangan, dan kuliah kerja nyata. Kedelapan tersebut dinamakan mata kuliah praktikum. Jadi perencanaan kurikulum yang jelas-jelas bermuatan praktik sudah mencapai 8 dari 63 mata kuliah, atau 20 sks dari 155 sks. Prosentasinya mencapai $12,9 \%$ dari keseluruhan bobot kurikulum di STAIN. Di samping itu, masih ada dua puluh empat (24) mata kuliah yang bisa bernuansa praktik karena isi maupaun cakupannya memerlukan praktik sebagai lahitan bagi mahasiswa. Kedua puluh empat tersebut bermuatan praktikum mata kuliah. Artinya, mata kuliah itu disusun tidak semata-mata untuk praktik, tetapi di dalam isi mata kuliah itu memuat unsur untuk kerja praktik bagi mahasiswa. Misalnya mata kuliah fiqih ibadah membutuhkan praktik baik dalam bentuk simulasi, demosntrasi, atau lainnya.

b. Disamping delapan yang jelas sebagai mata kuliah praktikum, ada 
dua puluh bentuk mata kuliah bermuatan praktik. Dua puluh empat lainnya merupakan mata kuliah biasa, tetapi mempunyai muatan praktikum. Dari dua puluh empat itu, yang layak menjadi mata kuliah praktikum adalah statistik, baik yang deskriftif maupun inferensial.

c. Pelaksanaan pembelajaran untuk delapan mata kuliah praktikum, ditawarkan secara berurutan dari semester pertama hingga semester delapan. Urutannya, semester ke-1 praktikum bahasa Arab, semester ke-2 praktikum bahasa Inggris, semester ke-3 praktikum ibadah, semester ke-4 praktikum teknologi informasi pendidikan, semester ke-5 praktikum penelitian, semester ke- 6 praktikum profesi/micro teaching, semester ke-7 praktik profesi lapangan, dan semester ke-8 kuliah kerja nyata. Sedangkan evaluasi kurikulum bermuatan praktik di Sekolah Tinggi Agama Islam Negeri Kudus mengacu pada tata pembelajaran dan evaluasi di STAIN Kudus. Evaluasi kelulusan tiap mata kuliah ditentukan minimal nilai 2.00, kecuali mata kuliah Praktik Profesi Lapangan (PPL) harus mencapai nilai minimal 3,49.

\section{Saran}

Pengelola dan perencana kurikulum STAIN Kudus agar selalu konsisten mengembangkan kurikulum pada semua jurusan dan program studi yang ada di STAIN Kudus, terutama kurikulum yang bermuatan praktik untuk penguatan keterampilan mahasiswa. 
Kisbiyanto

\section{Daftar Pustaka}

Amin, Ahmad. Etika (Ilmu Akhlak) (terjemahan) Farid Ma`ruf. Jakarta: Bulan Bintang.

Bakker, Anton. Metode-metode Filsafat. Jakarta: Ghalia Indonesia.

Buku Pedoman Akademik Sekolah Tinggi Agama Islam Negeri Kudus.

Bungin, Burhan. 2003. Analisis Data Penelitian Kualitatif: Pemahaman Filososfis dan Metodologis ke Arah Penguasaan Model Aplikasi. Jakarta: PT. RajaGrafindo Persada.

De Vos. 1987. Pengantar Etika (terjemahan) Soejono Soemargono. Yogyakarta: Tiara Wacana.

Denzin, Norman, Kand Lincold, Yvonna S. 2000. Handbook ofQualitative Research (Second Edition). California: Sage Publication, Inc.

Matthew, Miles B, dan Huberman. 1992. Analisis Data Kualitatif . Terjemahan Tjetjep Rohendi. Jakarta: Universitas Indonesia.

McMillan, James H and Sally Schumacher. 2001. Research In Education A Conceptual Introduction. San Francisco: Longman.

Moleong, Lexy, J. 2000. Metodologi Penelitian Kualitatif. Yogyakarta: Rake Sarasin.

Nasution, S,. 1993. Pengembangan dan Inovasi Kurikulum. Jakarta: PT. Citra Aditya Bakti.

Nasution, S,. 1996. Metode Penelitian Naturalistik Kualitatif. Bandung: Tarsito.

Nizar, Samsul. 2002. Filsafat Pendidikan Islam Pendekatan Historis, Teoritis, dan Praktis. Jakarta: Ciputat Press.

Poedjawiyatna. 1985. Etika: Filsafat Tingkah Laku. Jakarta:Rineka Cipta.

Praja, Juhaya S. 1997. Aliran-aliran Filsafat dan Etika. Bandung: Tiara.

Robbins, Stephen P. 2008. Perilaku Organisasi (Edisi Kesepuluh). Terjemahan Benyamin Molan. Indonesia: Indeks.

Rofiq, Moh. 2009. Ilmu Pendidikan Islam Pengembangan Pendidikan Integratif di Sekolah, Keluarga, dan Masyarakat. Yogyakarta: LKiS.

Salam, Burhanuddin. 2000. Etika Individual: Pola Dasar Filsafat Moral. Jakarta: Rineka Cipta.

Satmoko, Retno, Sriningsih. 1999. Landasan Kependidikan: Pengantar ke Arah Ilmu Pendidikan Pancasila. Semarang: CV. IKIP Semarang Press.

Soetopo, Henyat dan Soemanto, Wasty. 1986. Pembinaan dan Pengembangan Kurikulum. Jakarta: PT. Bima Aksara.

Subandijah. 1996. Pengembangan dan Inovasi Kurikulum. Jakarta: PT. Raja Grafindo Persada.

Sudarminta. 1991. Filsafat Proses: Sebuah Pengantar Sistematika Filsafat.

36 Alfred North Whitehead. Yogayakarta: Kanisius. 
Studi Analisis Pengelolaan Praktikum Keagamaan Islam

Sugiyono. 2008. Metode Penelitian Pendidikan Pendekatan Kuantitatif, Kualitatif dan $R \& D$. Bandung: Alfabeta.

Suseno, Franz Magnis. 1987. Etika Dasar. Yogyakarta: Kanisius.

Tilaar, HAR. 1999. Pendidikan, Kebudayaan dan Masyarakat Madani Indonesia. Bandung: PT. Remaja Rosda Karya.

Tjiptono, Fandy, Anastasia Diana. 2000. Total Quality Manaaagement. Yogyakarta: Penerbit Andi.

UU RI No. 20 Tahun 2003 tentang Sistem Pendidikan Nasional.

UU RI No. 12 Tahun 2012 tentang Pendidikan Tinggi.

Vembriarto, St,. 1993. Pengantar Perencanaan Pendidikan. Jakarta: PT. Grasindo. 